\title{
Prolegomena to Bentley's Unfinished New Testament Project
}

\author{
An-Ting Yi \\ Vrije Universiteit Amsterdam, Amsterdam, The Netherlands \\ an-ting.yi@vu.nl \\ Jan Krans \\ Protestantse Theologische Universiteit / Vrije Universiteit Amsterdam, \\ Amsterdam, The Netherlands \\ j.l.h.krans@pthu.nl \\ Bert Jan Lietaert Peerbolte \\ Vrije Universiteit Amsterdam, Amsterdam, The Netherlands \\ l.j.lietaertpeerbolte@vu.nl
}

\begin{abstract}
It is well known that the eighteenth-century classical scholar Richard Bentley once announced but never finished an ambitious project for a critical NT edition. What is less well known is that numerous entries of his archive have been preserved in Wren Library of Trinity College (TCL), Cambridge, until today. This article provides some prolegomena to a comprehensive enquiry into Bentley's unfinished NT project. It includes an updated summary of the archive, relevant secondary literature, a few examples for illustration, and on the basis of all this, some suggestions for future study.
\end{abstract}

\section{Keywords}

Richard Bentley - New Testament - textual criticism - history of scholarship - Wren Library - Trinity College Cambridge 
In the field of classical scholarship, Richard Bentley (1662-1742) is well known and regarded as one of the most important British scholars of all time. ${ }^{1}$ In NT studies in general and NT textual criticism in particular, Bentley is famous for his Proposals for Printing, published in 1720, in which he announced the preparation of a critical edition of both the Greek NT and its Vulgate version. ${ }^{2}$ Bentley was confident that by comparing the most ancient Greek and Latin manuscripts known in his day, a fourth-century text could be reconstructed. This new edition was intended to replace Stephanus' $155^{\circ}$ text, now known as the Textus Receptus (TR). ${ }^{3}$ Bentley also gave a specimen of Revelation 22 to offer a fresh text with at least forty-seven changes from the Stephanus text, among them nearly forty identical to the modern critical text.

In the early eighteenth century a project as the one proposed by Bentley was pioneering in respect to its ambitious aims and methodology. ${ }^{4}$ Regrettably,

* Many primary materials could not have been collected without the support of the staff of Wren Library of Trinity College, in particular its librarian, Nicolas Bell. We are grateful for their professional help and generosity during our stay in Cambridge, November 2018. We also thank CLUE+ (Research Institute for Culture, Cognition, History, and Heritage) and the Faculty of Religion and Theology of the Vrije Universiteit Amsterdam for facilitating this research visit. The first author amassed the underlying data and wrote a first draft of this article, and the authors together have consistently discussed the analysis of the data and composed the article in its present version. The images in this article are reproduced with kind permission of Wren Library.

1 See, e.g., C.O. Brink, English Classical Scholarship: Historical Reflections on Bentley, Porson, and Housman (Cambridge: Clarke, 1986). For a thorough investigation of Bentley's life, see J.H. Monk, The Life of Richard Bentley, D.D. Master of Trinity College, and Regius Professor of Divinity in the University of Cambridge: With an Account of His Writings, and Anecdotes of Many Distinguished Characters During the Period in Which He Flourished (2 vols.; and ed.; London: Rivingtons, 1833).

2 See, e.g., S. Neill and N.T. Wright, The Interpretation of the New Testament, 1861-1986 (2nd ed.; Oxford: Oxford University Press, 1988) 69-70; B.M. Metzger and B.D. Ehrman, The Text of the New Testament: Its Transmission, Corruption, and Restoration (4th ed.; Oxford: Oxford University Press, 2005) 156-157. This is a four-page pamphlet, printed probably at Cambridge as R. Bentley, $\eta$ xalv $\delta_{1}\left(\vartheta \eta x \eta\right.$ Graece: Novum Testamentum versionis Vulgatae, per St ${ }^{u m}$ Hieronymum ad vetusta exemplaria Graeca castigatae et exactae. Utrumque ex antiquissimis Codd. Mss, cum Graecis tum Latinis, edidit ... Proposals for Printing (n.p., 1720).

3 Commonly, the term TR is connected with the words written by Daniel Heinsius in the preface to the 1633 Leiden edition of Elzevir ("Textum ergo habes, nunc ab omnibus receptum: in quo nihil immutatum aut corruptum damus ..."), but the term itself only started to be used around 1800 .

4 Commonly, Karl Lachmann's 1831 edition is regarded as dethroning the TR in the way Bentley would have wanted. In reality, the change from the TR to the Modern Critical Text was a 
Bentley's promise was never fulfilled: except for the sample chapter, nothing was ever to be published of this project, at least during his lifetime. About half a century after his death, most of the materials related to this NT project were bequeathed to Trinity College, Cambridge, where he had served as Master for more than four decades. Bentley's archive remains in Wren Library of Trinity College (hereafter: TCL) until today.

Although textual critics of later generations have often cited his theory on how to make a critical edition, ${ }^{5}$ the way in which Bentley was actually preparing his edition is a neglected area in NT textual scholarship. ${ }^{6}$ Since the edition per se never materialised, the only way to study and understand Bentley's NT project is to explore those remaining archive entries. An exploration of this kind should necessarily begin with an overview of the TCL collection. While a few archive entries have been particularly examined, ${ }^{7}$ the only available introduction to the archive as a whole is a mid-nineteenth century treatment. ${ }^{8}$ Given the profound developments of text-critical studies in the past 150 years, that introduction has in many aspects become outdated.

Based on our first-hand investigation in Cambridge, this article aims to provide an up-to-date overview of the Bentley archive. After a brief section on the changes of the archive in the course of time ( $\$ 2)$, an updated summary of the whole collection is offered $(\$ 3)$. After this, several examples illustrate the value of historical study such as this $(\S 4)$. Some concluding remarks indicate future directions for a comprehensive enquiry into Bentley's NT project (\$5). Given the limited space available here, this study should merely be seen as prolegomena to one of the largest and arguably most important eighteenth-century projects of a critical edition of the NT. ${ }^{9}$

long process. See K. Lachmann, Novum Testamentum Graece ex recensione Caroli Lachmanni (Berlin: Reimer, 1831).

5 See, e.g., the most recent citations in D.C. Parker, "The Future of the Critical Edition," in The Future of New Testament Textual Scholarship: From H.C. Hoskier to the Editio Critica Maior and Beyond (ed. G.V. Allen; wUNT 417; Tübingen: Mohr Siebeck, 2019) 395-405, here 395-399.

6 Contemporary scholarship on Bentley's NT mostly depends on the material published by Ellis in 1862 (see below).

7 E.g., Woide on Adv.e.2.2 (B.17.3), Ellis on B.17.20, Wordsworth on the Latin text (see n. 21 below).

8 R. Bentley, Bentleii Critica Sacra: Notes on the Greek and Latin Text of the New Testament, Extracted from the Bentley Mss. in Trinity College Library (ed. A.A. Ellis; Cambridge: Deighton, Bell, and Co., 1862) xxvii-xlv.

9 A more extensive description of all the TCL Bentley materials mentioned here will be published by us in a forthcoming issue of the TC Journal, entitled, "A New Descriptive Inventory of Bentley's Unfinished New Testament Project”; see http://jbtc.org. 


\section{Bentley's Archive in History}

Before describing the current status of the Bentley NT material in the TCL archives, a sketch of its history is needed. Shortly before his death in 1742, Bentley penned his will to leave all his literary materials to his nephew Richard Bentley, fellow of Trinity College. The younger Richard died in 1786 and bequeathed many of his uncle's collections to Trinity College, including those related to the unfinished NT project. ${ }^{10}$ The library then catalogued the bequeathals under the class number "B.17."11

Soon after its inclusion in the library, one of the archive entries (Mico's collation of Bo3; Adv.e.2.2 [B.17.3]) was examined by Charles Godfrey Woide, an oriental scholar from Oxford. Woide passed away in 179o, but his work was published posthumously nine years later. ${ }^{12}$ In the nineteenth century, several textual critics went to Cambridge to consult Bentley's archive, for instance Tregelles, Tischendorf, and Westcott. Eventually, in 1862, Arthur Ayres Ellis, fellow of Trinity College since 1855, extracted materials from the collection and published these as Bentleii Critica Sacra. ${ }^{13} \mathrm{He}$ also listed and briefly described every entry known to him. ${ }^{14}$ As mentioned above, to the present day this is the

10 Monk, Bentley, 2:415-416, 441-443 (on Bentley's will). It is said that there were thirteen printed editions of the Greek NT given to Trinity College; cf. R. Bentley, The Works of Richard Bentley, D.D. ..., vol. 3: Theological Writings (ed. A. Dyce; London: Macpherson, 1838) 483-484. All of those have been preserved except Adv.a.2.1 (B.17.5; see below).

11 Class B contains the theological manuscripts in TCL; cf. M.R. James, The Western Manuscripts in the Library of Trinity College, Cambridge: A Descriptive Catalogue, vol 1: Containing an Account of the Manuscripts in Class B (Cambridge: University Press, 190o) vii-x. The catalogue itself, recorded in 1786 (with additional remarks in the nineteenth century), is numbered B.17.19.

12 C.G. Woide, Appendix ad editionem Novi Testamenti Graeci e codice ms. Alexandrino a Carolo Godofredo Woide descripti, in qua continentur fragmenta Novi Testamenti iuxta interpretationem dialecti superioris Aegypti quae Thebaidica vel Sahidica appellatur, e codicibus Oxoniensibus maxima ex parte desumpta, cum dissertatione de versione bibliorum Aegyptiaca [ab eodem], quibus subiicitur codicis Vaticani collatio (ed. H. Ford; Oxford: Clarendon, 1799). Woide actually shared the information on Bo3 from Luke and John with Andreas Birch, who included it in his 1788 work, Quatuor Evangelia Graece cum variantibus a textu lectionibus codd. mss. bibliothecae Vaticanae, Barberinae, Laurentianae, Vindobonensis, Escurialensis, Havniensis Regiae, quibus accedunt lectiones versionum Syrarum, veteris, Philoxenianae et Hierosolymitanae iussu et sumtibus regiis edidit ... (Copenhagen: Schultz, 1788); see esp. xxiv.

13 Ellis reproduces a collection of Bentley's conjectures, the part of Galatians in Adv.a.2.2 (B.17.6), and the collation of Bo3 in B.17.20.

14 Based on his own examination and Ellis' work, Scrivener also mentions some archive entries in F.H.A. Scrivener, A Plain Introduction to the Criticism of the New Testament for the Use of Biblical Students (2 vols.; ed. E. Miller; 4th ed.; London: Bell, 1894) 2:207-209. 
only available catalogue of the subject under discussion. Valuable as it may be, there are a number of problems that make it less useful for today.

Firstly, TCL converted its archive numbering system at the beginning of the twentieth century. The new system transferred all of Bentley's annotated printed editions to the category "Adv" (representing adversaria in Latin). Only the ones purely manuscript in nature have remained in B.17. As a result, Ellis' catalogue numbers are no longer in use, and thus need to be converted to the current system. ${ }^{15}$ Secondly, Ellis did not present a verbatim transcript of Bentley's notes, but edited them for the convenience of his readers, thus actually introducing a filter between Bentley's material and its students, and blocking from their view the layers and the work in progress. Furthermore, Ellis only referred to Adv.d.2.4 (B.17.9) for many of Bentley's notes, but did not mention the sources of the remainder. The third problem is the selective nature of Ellis' work.

Scholars in the twentieth and twenty-first centuries seem to pay less attention to Bentley's material in the TCL collection, but one exception should be mentioned. In her 2011 monograph on Bentley, the classical scholar Kristine Louise Haugen discusses a number of his NT conjectures found in the archive. In a footnote she also lists many entries with their current shelf marks. ${ }^{16}$ However, Haugen does not intend to provide an overview such as the one offered here, and her list only focuses on the printed Greek NT editions without giving the corresponding old shelf marks.

There are further elements that can help us to examine the archive more easily. From 2013 onwards the library has been digitising many of its manuscripts, making them available online. ${ }^{17}$ Three entries in B.17 are included $(17.1,17.2,17.20)$. The online library catalogue also offers basic information and a brief note on each entry.

According to our examination at TCL, the library currently contains thirteen of Bentley's annotated NT editions in the Adv collection and five manuscripts related to his NT project classified as B.17. ${ }^{18}$ Comparison with Ellis' list shows that he seems to have overlooked one entry (B.17.4O) and that the title B.17.5

15 Furthermore, those old shelf marks have been reused for documents of Bentley and his contemporaries. For instance, if one wants to check Mico's collation by following the information given by Ellis (i.e., B.17.3), one would actually consult a collection irrelevant in matters text-critical: the records of the dispute between Trinity College and Bentley.

16 K.L. Haugen, Richard Bentley: Poetry and Enlightenment (Cambridge, MA: Harvard University Press, 2011) 187-210 and esp. 300-301 n. 9. This footnote in fact served as our starting point for checking the current status of the Bentley archive.

17 See https://mss-cat.trin.cam.ac.uk for further information (accessed 27 January 2020).

18 Apart from these, there are some other NT manuscripts that once belonged to Bentley: B.8.5A (o131), B.10.16 (minuscule 489), B.10.17 (minuscule 477). 
(new shelf mark Adv.a.2.1) is unfortunately missing today. ${ }^{19}$ An updated summary of the whole collection is offered in the next section.

\section{$3 \quad$ An Updated Summary}

In what follows an up-to-date summary of the entire archive of Bentley's NT project is provided, as it survives to the present day. Three categories deserve to be distinguished.

First and foremost, there is an interleaved NT edition, containing numerous of Bentley's handwritten notes (Adv.a.2.2 [previously B.17.6]). This volume was his working text and his repository of collations in the course of the preparation of his NT edition. ${ }^{20}$ To put it more precisely, Bentley corrected the base text on every single printed page by indicating the readings he preferred, with the corresponding textual apparatus on the facing interleaved page (see $\S 4.5$ for illustration). ${ }^{21}$

Second, most of the Adv entries are printed editions annotated by Bentley or his assistants, notably Johann Jakob Wettstein (1693-1754) and John Walker (1692[?]-1741), twelve editions in total. ${ }^{22}$ One can find many collations of Greek and Latin NT manuscripts as well as patristic citations, be them made in Cambridge, London, Paris, or even further away. A notable example is a Greek NT edition of 1675, currently numbered Adv.e.2.2, which contains Apostolo Mico's collation of Codex Vaticanus (Bo3). There is also a letter inserted that Mico sent from Rome to Mead in London (see §4.3). The collation includes

19 According to previous scholarship, it appears to have contained collations of Greek and Latin manuscripts; see Bentley, Critica sacra, xxxv-xxxix; B.F. Westcott, "Vulgate, The," $D B(S) 3$ (1863) 1688b-1718a, here 1709 n. e.

20 See R. Bentley, The Correspondence of Richard Bentley, D.D. Master of Trinity College, Cambridge (2 vols.; ed. C. Wordsworth; London: Murray, 1842) 522-523 (no. 197). The part of Revelation 22 in this volume is identical to the specimen in his Proposals for Printing (cf. Bentley, Critica sacra, xxiii; Scrivener, Introduction, 2:208-209).

21 Besides Ellis' work on the part of Galatians (Bentley, Critica sacra, 93-117), the Latin text and the correlated apparatus in this volume were examined by John Wordsworth for the well-known "Oxford Vulgate," in which Bentley's text-critical decisions are regularly referred with the abbreviation "Bentl."; cf. J. Wordsworth and H.J. White, eds., Novum Testamentum Domini nostri Iesu Christi Latine secundum editionem sancti Hieronymi, pt. 1: Quattuor evangelia (Oxford: Clarendon, 1898) xv-xxvii.

22 Adv.a.2.3 (B.17.12), Adv.a.2.4 (B.17.13), Adv.bb.2.1 (B.17.14), Adv.b.2.2 (B.17.34), Adv.d.2.3 (B.17.8), Adv.d.2.4 (B.17.9), Adv.d.2.5-6 (B.17.42-43), Adv.d.2.7-8 (B.17.44-45), Adv.e.2.1 (B.17.4), Adv.e.2.2 (B.17.3), Adv.e.2.3 (B.17.7), and Adv.e.2.4-5 (B.17.10-11). 
every book in the NT of the remaining uncial part of Bo3, but also variant readings from its supplement, Hebrews 9-13 and Revelation (GA number: 1957). ${ }^{23}$

Bentley also employed these printed editions for recording his critical opinions on the NT text. In the text part of Adv.a.2.4 (Mill's 1707 NT edition), Bentley mainly copied citations from Origen, while in the Prolegomena part he added some remarks to the manuscript list (see $§ 4.2$ below). Further, in another 1675 edition (Adv.d.2.4), he wrote down many of his conjectures in the margins as well as on the first and last pages (see $§ 4.4$ for illustration). ${ }^{24}$

Third, in the "James Catalogue of Western Manuscripts," a number of valuable items deserve attention as well. ${ }^{25}$ Among them are B.17.1, Codex Augiensis (Fo10), and B.17.2, a copy of Codex Boernerianus (Go12), which can be regarded as a pre-industrial pseudo-facsimile. Both Codices Augiensis and Boernerianus are ninth-century Greek-Latin bilingual majuscules of the Pauline epistles. There is also a folio volume, B.17.20, containing a mass of papers, most of them related to Bentley's NT project. ${ }^{26}$ Besides, B.17.21 (previously B.17.34a) contains the catalogue of Walker's collations in Adv.b.2.2, and B.17.40 (previously B.17.15) is a notebook of a collation of two manuscripts, which according to our examination are Go11 and Ho13 (see §4.1).

Apart from offering an up-to-date summary, a detailed examination into the Bentley archive also offers plenty of new insights into his NT project. In what follows we select a few examples to illustrate the importance of examining the archive directly.

\subsection{Newly Identified Collation}

During our stay in Cambridge, we discovered one entry seemingly unknown to previous scholarship, numbered B.17.40 with the library title "New Testament." It contains a collation of two manuscripts, referred to as A and B. The collation, sixteen pages in the form of a quaternion, includes more than 500 variant readings starting at Matt 6:7 for manuscript A and Matt 15:32 for manuscript $\mathrm{B}$, and ending at John 12:22 for both. Based on the points where the collations

\footnotetext{
23 The collation was later published in 1799; see $§ 2$ above.

24 The volume is thus called by Haugen as the "1716 conjecture book" (Bentley, 206-207).

25 See James, Catalogue, 1:544-549 (nos. 412-415). The catalogue has been digitised and can be found online at https://mss-cat.trin.cam.ac.uk/search.php (accessed 27 January 2020).

26 For an overview of the content and the digital images, see http://mss-cat.trin.cam.ac.uk/ viewpage.php?index=312\&history $=\mathbf{1}($ accessed 27 January 2020).
} 


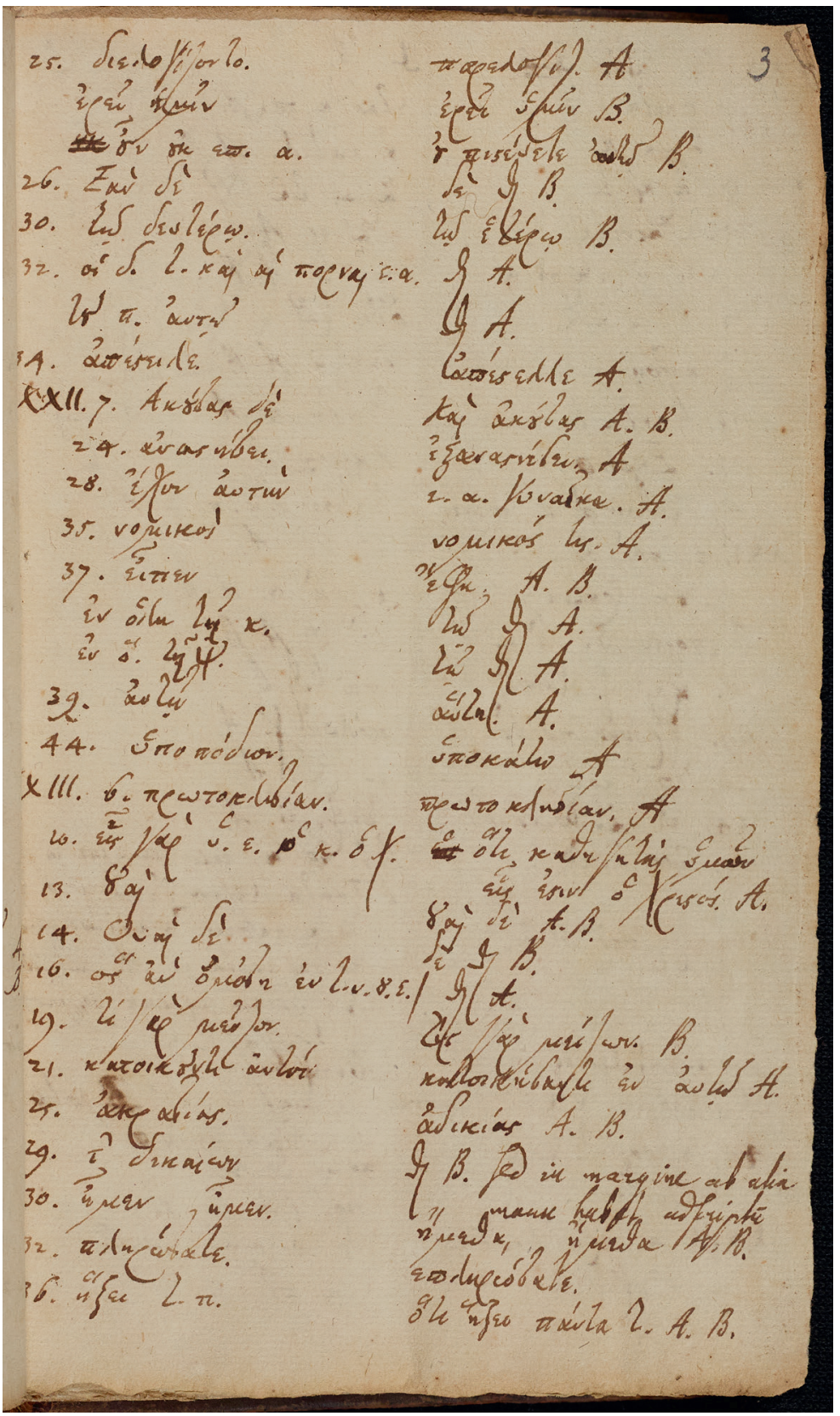

FIGURE $1 \quad$ B.17.4O, f. $3^{\mathrm{r}}$ (Matt 21-23) REPRODUCED BY PERMISSION OF WREN LIBRARY OF TRINITY COLLEGE, CAMBRIDGE 
begin, and on a number of typical readings, the identification of these two manuscripts is not hard to make: it concerns Codices Wolfii A and B (Go11 and Ho13). ${ }^{27}$ Further comparison with Adv.a.2.3, in which variants of Goll and Ho13 - also with the sigla A and B - are found, shows that many pieces of information are identical to those in the collation. In Bentley's day the two codices were owned by Johann Christoph Wolf (1683-1739), who sent one folio of each of them from Hamburg to Bentley in Cambridge, probably intended as specimens of this collation. ${ }^{28}$

\subsection{Identification of Stephanus' $\beta^{\prime}$}

Bentley not only used Adv.a.2.4 (Mill's NT edition of 1707) to record the citations from Origen, but he also made marginal notes on those pages concerning Mill's descriptions of manuscripts. An intriguing example is found on the part of the manuscripts used in Stephanus' $155^{\circ}$ edition. On the right margin of page cxvii, where Mill discusses Stephanus' $\beta^{\prime}$, Bentley wrote down his comment: "This is the Cambridge manuscript itself-which belonged to Bezabut collated extremely carelessly."29 This judgement is remarkable in light of early-eighteenth-century text-critical scholarship, since the identification of Stephanus' manuscripts has confused textual critics for a long period of time. Mill for instance did not consider Stephanus' $\beta^{\prime}$ to be "codex Cantabrigiensis" and instead regarded these two as different manuscripts. ${ }^{30}$ Even later in Wettstein's day the fact that the siglum $\beta^{\prime}$ actually represents Codex Bezae (Do5) was still contested. ${ }^{31}$ Bentley's judgement was possibly based on his

27 E.g., manuscript A omits the last clause $\alpha$ px

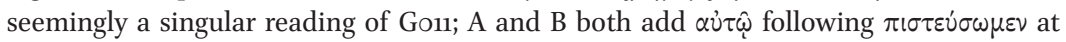
Mark 15:32. Many variants correspond to J.C. Wolf, Anecdota Graeca, sacra et profana, ex codicibus manu exaratis nunc primum in lucem edita, versione Latina donata, et notis illustrata, vol. 3 (Hamburg: Felginer, 1723) 48-92, yet the published version has more variant readings.

28 See Bentley, Correspondence, 580-581 (no. 224) for a letter from Wolf to Bentley, dated October 1721.

29 Adv.a.2.4, p. cxvii: "Est ipse codex Cantabrigiensis (qui Bezae fuit) sed negligentissime collatus."

30 In the place where Mill mentions the Cambridge manuscript, Bentley simply writes "Codex Bezae" on the margin (Adv.a.2.4, p. cxxxi).

31 J.J. Wettstein, 'H Kalvं $\Delta \iota \alpha \vartheta \dot{\eta} x \eta$ : Novum Testamentum Graecum editionis receptae cum lectionibus variantibus Codicum Mss., Editionum aliarum, Versionum et Patrum nec non commentario pleniore ex Scriptoribus veteribus Hebraeis, Graecis et Latinis historiam et vim verborum illustrante (Amsterdam: Dommeriana, 1751-1752) 1:35-38; see also J. Krans, Beyond What Is Written: Erasmus and Beza as Conjectural Critics of the New Testament (NTTS 35; Leiden: Brill, 2006) 227-236 for a thorough analysis on this topic, in particular regarding to Beza. 
O M E N A. CXVII autem, eorum numero recenfet Lucas Brugen/is, qui ad verfionem Vulgatam efformati fuerint. "Libenter, inquit, "confonat Editioni Latina". Ad Latina caftigatum, vebe"mens mibi Jufpicio eft, curn ex boc loco, turn ex aliis plu"ribus b. Latince Editioni contra alia ommia (Stephanica) " Jape confonat, or aliquando erroribus potius ejus Editio"nis inolitis, quam germane lectionic. Jam diu difcimus "Exemplar, pro audacis fcribe arbitrio, difcrepare frequen"ter à cateris, Go fere quidem ad Latinam Editionem mu"tatum. " Hæc ille. Certe $\mathrm{ex}$ variationibus iftius Codicis, quas circiter ccccLxxxv numerat Editio Stephani tertia, pauciores paulo prima \& fecunda, illa ecccxxxvIr, hæc cCCCXIIII. (admiffis fcrilicet in utriufque hujus contextum multis Codicis $\beta^{\prime}$ lectionibus, is præfertim, in quibus Codex ifte confonat cum lectionibus Steph. omn. quas in interiorem marginem rejecit tertia) non aifi decem confpexi-

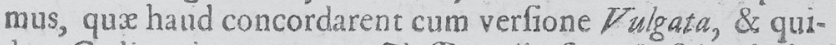
dem Codice ejus corrupto, Glolfematibufque \& fubinde integris Mrenotais fatis prolixis, in AEtis præfertim Apostolo. rum interpolato.

FIGURE 2 Adv.a.2.4, p. cxvii (part)

REPRODUCED BY PERMISSION OF WREN LIBRARY OF TRINITY COLLEGE, CAMBRIDGE

examination of the manuscript. He may even have discussed the matter with Wettstein, who published the same conclusion in $173^{\circ} .^{32}$

\subsection{Details on Mico's Collation}

Scholars have long known of Mico's collation of Bo3, made around 1720, but there is no direct source providing a specific date for its production. ${ }^{33}$ However, the letter inserted in Adv.e.2.2 may shed some light on this particular issue. It is a letter written from Rome by the collator Mico, dated 28 July 1722, to "Doctor

32 J.J. Wettstein, Prolegomena ad Novi Testamenti Graeci editionem accuratissimam, e vetustissimis codd. Mss. denuo procurandam; in quibus agitur de codd. Mss. N. Testamenti, Scriptoribus Graecis qui N. Testamento usi sunt, versionibus veteribus, editionibus prioribus, et claris interpretibus; et proponuntur animadversiones et cautiones ad examen variarum lectionum N.T. necessariae (Amsterdam: Wettstein \& Smith, 1730) 22.

33 E.g., C.M. Martini, Il problema della recensionalità del codice B alla luce del papiro Bodmer XIV (AnBib 26; Rome: Pontificium Institutum Biblicum, 1966) 12. 


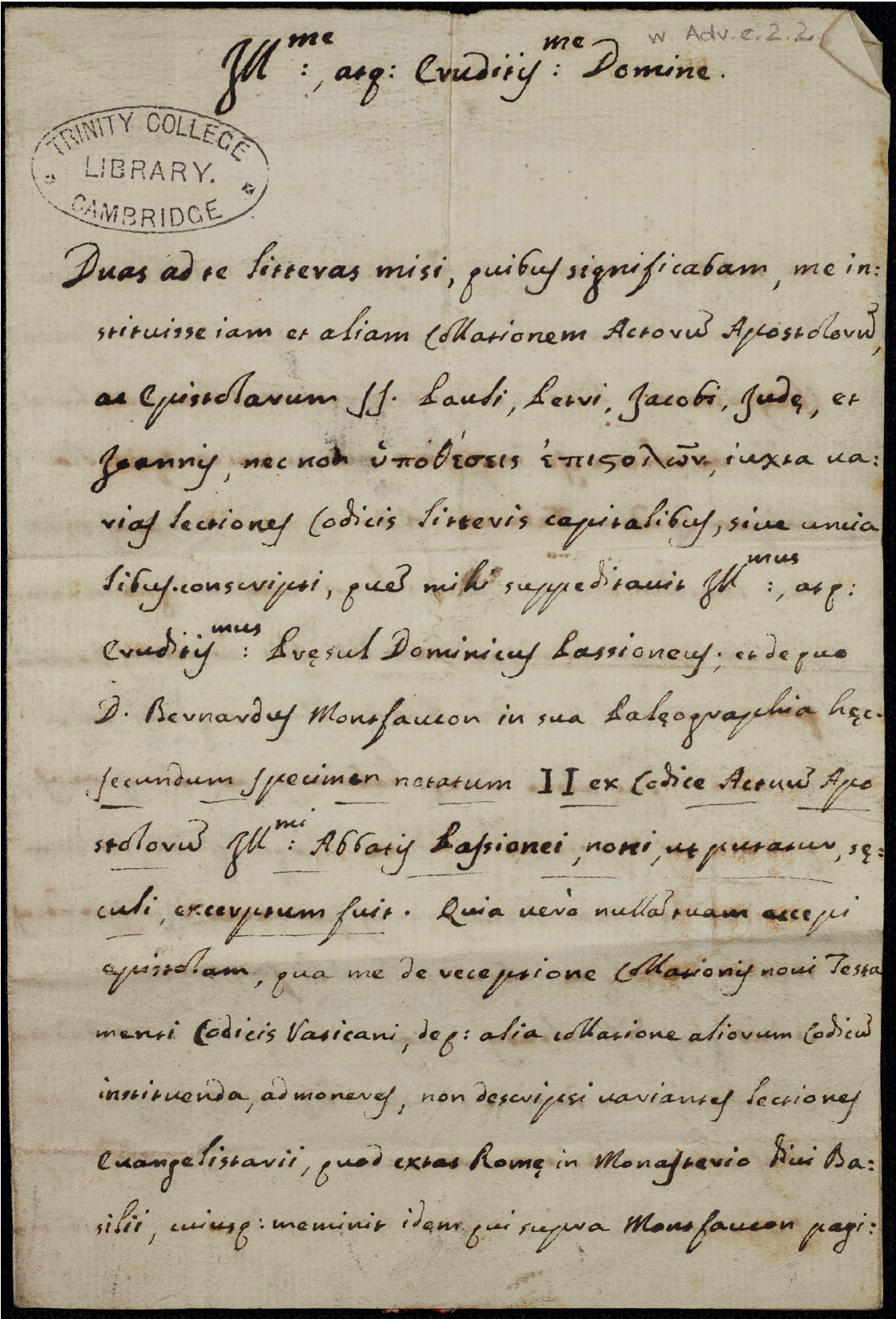

FIGURE 3 Inserted letter in Adv.e.2.2, f. $1^{\mathrm{r}}$

REPRODUCED BY PERMISSION OF WREN LIBRARY OF TRINITY COLLEGE,

CAMBRIDGE 
Meade" in London, that is, Bentley's close friend Richard Mead. ${ }^{34}$ In the letter Mico informs Mead that he has not yet received any confirmation from Mead concerning his reception of the collation of Bo $3 \cdot{ }^{35}$ Several lines later Mico provides another piece of information, viz. that he only received one letter from Mead, dated 20 February $1721 .^{36}$ Accordingly, this letter implies that Mead would have been Bentley's agent in finding a suitable amanuensis for the manuscript and that Mico could have made the collation between Mead's request in the winter of 1721 and the current letter in the summer of 1722 . Therefore Bentley would have received the collation only after the announcement of his Proposals for Printing in 1720. Furthermore, to our knowledge, Mico's letter has not been transcribed and published before, probably due to the fact that Bentley is not its recipient. A transcription is now included in the Appendix.

\subsection{Modifications of Bentley's Conjectures}

It is well known that Bentley proposed conjectures by the hundreds, both on classical works and the NT. ${ }^{37}$ Yet, only a few of the NT conjectures are found in Bentley's own publications, whereas many others were first listed by Wettstein in his 1730 Prolegomena. ${ }^{38}$ Moreover, Ellis also published a considerable number of conjectures that he found in Bentley's hand editions. Now, by looking into the archive entries themselves, some additions and corrections can be made. For instance, according to Wettstein, there is a conjecture at Col 1:12

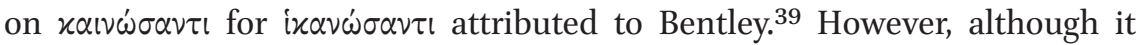

34 Mead was a renowned physician; two letters between him and Bentley are preserved in Bentley, Correspondence, 581-592 (nos. 225 and 226).

35 "Since truly I have not received any letter from you, in which you inform me about the reception of the New Testament collations of the Vatican manuscript ..." ("Quia vera nullam tuam accepi epistolam, qua me de receptione Collationes novi Testamenti Codicis Vaticani, ... admoneres," f. $\mathrm{r}^{\mathrm{r}}$ ). Later in the letter Mico complains that he had sent a number of other letters that apparently never arrived.

36 "... as seen in your first and only letter written in London on February 20, 1721" (“... ut videre est in prima sua, et unica epistola scripta Londini Februarii 20. 1721," f. 1v).

37 In The Amsterdam Database of New Testament Conjectural Emendation, there are more than 130 conjectures recorded Bentley as Urheber, see http://ntvmr.uni-muenster.de/nt -conjectures?authorID=a1038 (accessed 27 January 2020).

38 Prolegomena, 170-174. It should be noted that Wettstein omitted Bentley's name for these conjectures, except for the ones that Bentley himself has published. See further J. Krans, “'Mon cher cousin': Johann Jakob Wettstein's Letters to His Cousin Caspar," in Goldene Anfänge und Aufbrüche: Johann Jakob Wettstein und die Exegese der Apostelgeschichte (ed. M. Lang and J. Verheyden; Arbeiten zur Bibel und ihrer Geschichte 57; Leipzig: Evangelische Verlagsanstalt, 2016) 49-64, here 59-6o.

39 Prolegomena, 173; Wettstein here omits Bentley's name, but does supply it in NTG, 2:282. See cj10688: http://ntvmr.uni-muenster.de/nt-conjectures?conjID=cj10688 for further information (accessed 27 January 2020). 


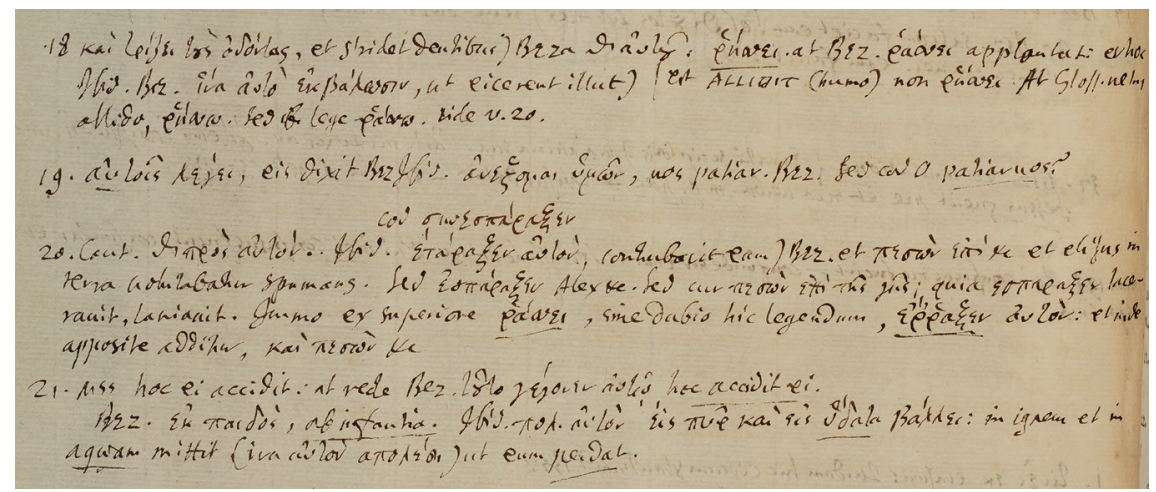

FIGURE 4 Adv.a.2.2, p. 65 suppl. (part)

REPRODUCED BY PERMISSION OF WREN LIBRARY OF TRINITY COLLEGE, CAMBRIDGE

is indeed recorded on the bottom of page 510 in Adv.d.2.4, this very conjecture has actually been crossed out. This might suggest that Bentley no longer saw any value in the idea. Another example can be seen in Ellis' collection of Bentley's conjectures. Ellis cites a conjecture on Mark 9:20, namely हैppa $p \varepsilon v$ instead of $\dot{\sigma} \sigma \pi \dot{\alpha} \rho \alpha \xi \varepsilon v$. In fact, the wording as rendered by Ellis is slightly different from what we find in Bentley's annotation in Adv.a.2.2. ${ }^{40}$ This shows that Ellis made some editorial changes in order to provide a smoother and more readable text, thus in a way presenting Bentley's apparatus more like a final product than it actually was. ${ }^{41}$

\subsection{Bentley's Work-in-Progress}

As mentioned above, Ellis published a number of extracts from the TCL collection, and his labour still deserves praise. However, he not only consistently "corrected" Bentley's handwritten notes as found in Adv.a.2.2 and Adv.d.2.4, ${ }^{42}$

40 Critica sacra, 9; Adv.a.2.2, p. 65 suppl. See the citation in cj1259o for comparison: http:// ntvmr.uni-muenster.de/nt-conjectures?conjID=cj1259o (accessed 27 January 2020).

41 Ellis admits that some modifications are made: "In printing these [Bentley's conjectures] interesting remains for the use of scholars of our own day, the Editor has taken the liberty to adopt the notation of MSs. introduced by Wettstein, which was of course unknown to Bentley: who always quotes Codices A. B. C. D. as Cod. Alex., Cod. Rom., Cod. Ephr., Cod. Bezae, or 'Cant.' In the Edition of the Galatians, Bentley's notation has been preserved as it stands in the MS" (Critica sacra, xxii). But there are actually more changes than Ellis states; other examples are cj15207 and cj11317. It should be noted that by these transformations Ellis in a way deprives Bentley's work of its personal and vivid character.

42 Apart from the collection of the conjectures, similar modifications are made to the textual apparatus in the part of Galatians in Adv.a.2.2 (B.17.6). 


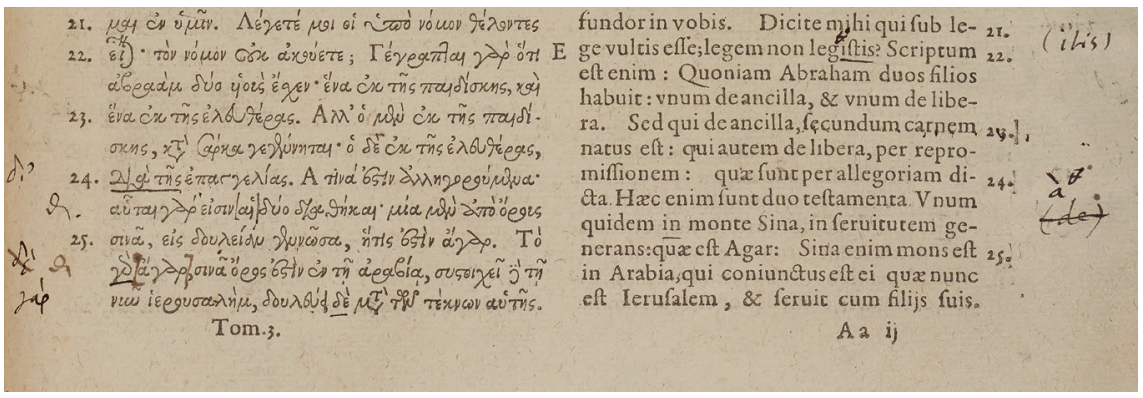

FIGURE 5 Adv.a.2.2, p. 279 (part; note that Bentley always uses the particular sign [similar to $\vartheta]$ for omissions)

REPRODUCED BY PERMISSION OF WREN LIBRARY OF TRINITY COLLEGE, CAMBRIDGE

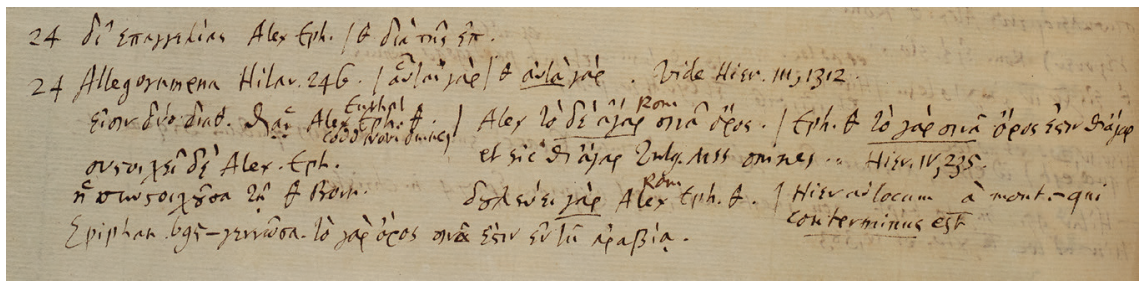

FIGURE 6 Adv.a.2.2, p. 279 suppl. (part)

REPRODUCED BY PERMISSION OF WREN LIBRARY OF TRINITY COLLEGE, CAMBRIDGE

but also mostly presented the notes in their final stage, thereby omitting some interesting in-progress elements. The importance of these elements is that they show the way in which Bentley made text-critical decisions. An example is found at Gal 4:25, one of the best-known textual variants in the whole NT. On page 279 of Adv.a.2.2, the base text starts this verse with Tò $\gamma \dot{\alpha} \rho \alpha \gamma^{\prime} \alpha \rho, \sigma v \hat{\alpha}$

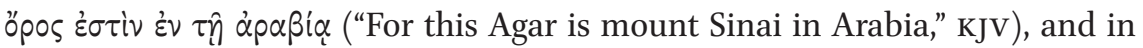

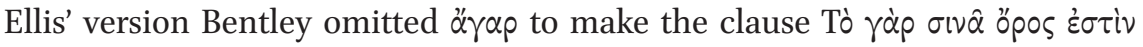

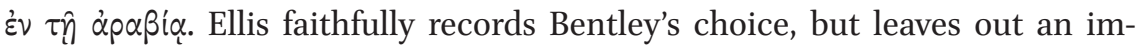
portant aspect of Bentley's text-critical deliberation. ${ }^{43}$ In the margin of the page Bentley first wrote $\delta \dot{\varepsilon}$ beside verse 25 and also underlined $\gamma \alpha \dot{p}$ in the text. Later, however, this $\delta \dot{\varepsilon}$ has been crossed out again, indicating that Bentley then regarded the original reading yáp as correct. He also added omission signs to $\alpha$ rap. In our reconstruction this is a later change, probably made after taking

43 Bentley, Critica sacra, 108-109 (including the corresponding apparatus). 
some more evidence into account. In short, we assume the following three-

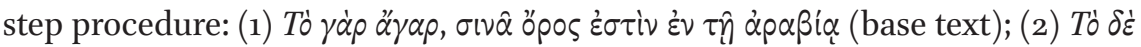

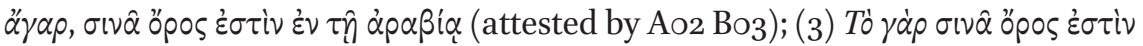

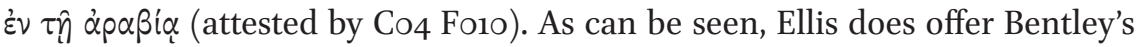
final decision, but the process leading to it is worth studying as well.

\section{$5 \quad$ Concluding Remarks}

Already in 1862, Ellis complained that he was able to publish only a few extracts from the Bentley collection. ${ }^{44}$ More than a century and a half later, most of the archive is still kept on the bookshelves and remains unexplored. The present article of course cannot fulfill Ellis' wishes, but we do hope that it will serve as point of departure for future research. The overview offered here can be seen as a map for those who intend to explore the rich field of Bentley's NT materials. Challenging as that task surely is, the reward is likely to be fruitful. As shown in $\S 4$, a close examination of this collection not only contributes to the knowledge of Bentley's NT project and the materials he collected, but it can also deepen our understanding of his way of text-critical thinking, intellectual networks of his time, and even developments and discussions of textual scholarship in the eighteenth century.

The pressing question for now is: what should be the next step? On the one hand, based on our findings, an even more precise overview can be made of the resources Bentley used. Further examination can compare and verify the manuscripts that were collated, as well as compile a comprehensive list of Bentley's sigla with their current Gregory-Aland numbers. On the other hand, expedition and prioritising of the digitisation process would be more than welcome. Three titles have already been made available online. NT textual scholarship in general and scholarship on Bentley in particular would greatly benefit from digitisation of the whole collection. It might be good to start with Adv.a.2.2, soon followed by the more fragile items. In short, the advantages of the digital age now allow us to finally complete the project started more than three hundred years ago.

44 Bentley, Critica sacra, xxiii: "It would indeed be possible to print the whole of his revision, both of the Greek and Latin Text, with all the materials which he has accumulated for its illustration. But this would be a work of great labour and cost, and little likely to be executed at this day." 


\section{Appendix: Transcription of the Inserted Letter in Adv.e.2.2}

$\left[\mathbf{r}^{\mathrm{r}}\right]$ Illme $^{\mathrm{me}}$, atque Eruditis ${ }^{\mathrm{me}}$ Domine.

Duas ad te litteras misi, quibus significabam, me instituisse iam et aliam Collationem Actorum Apostolorum, ac Epistolarum SS. Pauli, Petri, Jacobi, Judae, et Joannis, nec

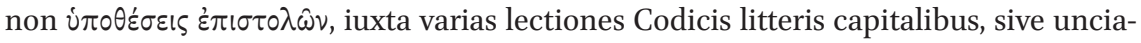
libus. conscripsi, quem mihi suppeditavit Illmus, atque Eruditis ${ }^{\text {mus }}$ Praesul Dominicus Passioneus; et deque D. Bernardus Montfaucon in sua Palaeographia haec. Secundum Specimen notatum II ex Codice Actuum Apostolorum Illmi Abbatis Passionei, noni, ut putatur, saeculi excerptum fuit. ${ }^{45}$ Quia vera nullam tuam accepi epistolam, qua me de receptione Collationes novi Testamenti Codicis Vaticani, deque alia collatione aliorum Codicum instituenda, admoneres, non descripsi variantes lectiones euangelistarii, quod extat Romae in Monasterio Divi Basilii, cuiusque meminit idem qui supra Montfaucon pagi $\left[1^{\mathrm{v}}\right]$ na $233,{ }^{46}$ et alterius, quod asservatur in Bibliotheca Vaticana, conscriptum, ut creditur, temporibus divi Joannis Chrysostomi; licet a te desiderarentur collationes huiusmodi, ut videre est in prima sua, et unica epistola scripta Londini Februarii 20. 1721. Miratus sane sum causam silentium, cum silentii causam ignorarem; omnem tamen admirationem discussit adventus Romam praestantissimi Viri dn̄i Andreae Hay: cognovi enim ex verbis, quae ultro citraque habuimus, non minus meas, quam tuas epistolas excidisse. Rogo igitur, ut, cum praesens haec mea in suas manus pervenerit, respondeas statim, simulque iubeas quid mihi faciendam, immo ut indigites dificultates, quas, mihi asserit dn̄is Andreas, collationi a me iam institutae, tibique

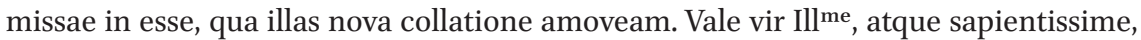
ac si aliqua in re me dignum, ut tibi in $\left[2^{\mathrm{r}}\right]$ serviam, existimas, iube, et pro meis viribus tibi faciam satis.

Romae 28 Julii 1722.

\section{Dear Sir}

I am sorrij that packett of Letters which I sent to Sign Don. Apostolo his been miscaried though I put it in my self att the Generall Post office, I left mr Alderman Barber ${ }^{47}$ att Naples 10 daijs ago he is much recovered by the journey and the air of Naples, I have

45 The citation is from B. de Montfaucon, Palaeographia Graeca, sive De Ortu et Progressu Literarum Graecarum, et De variis omnium saeculorum Scriptionis Graecae generibus: Itemque de Abbreviationibus \& de Notis variarum Artium ac Disciplinarum. Additis Figuris \& Schematibus ad fidem manuscriptorum Codicum (Paris: Guerin, 1708) 513.

46 That is, de Montfaucon, Palaeographia, 233: "Secundum specimen prodit ex Codice RR. PP. S. Basilii Romae ..."

47 John Barber (bap. 1675, d. 1741), printer and politician, who became the alderman of Castle Baynard in 1722. He departed from England in April of the same year to Rome due to being implicated in the "Atterbury plot", an event that forced him to stay abroad until 1724 . 
bought som very good Pictures some Drawings and books-I shall be sure to take Care of your Commissions and any thing that I can serve you in whilst in this Place I hope you will comand your most obliged Humble servant

Andrew Haij ${ }^{48}$

my Humble service to Mr Houard

Addictissimus tuus famulus

Apostolus Micho

48 Andrew Hay (d. 1754), British portrait painter and picture dealer, who frequently visited Rome for buying paintings during the 1710 s and the 1720s; see I. Pears, The Discovery of Painting: The Growth of Interest in the Arts in England, 1680-1768 (New Haven, CT: Yale University Press, 1988) 77-87. It thus seems that Hay ensured the communication between Mico and Mead. 